\title{
Not Only Why but Also How to Trust Science: Reshaping Science Education Based on Science Studies for a Better Post-pandemic World
}

\author{
Nathan Willig Lima ${ }^{1}$ Matheus Monteiro Nascimento ${ }^{1}$
}

Accepted: 9 November 2021 / Published online: 9 January 2022

(c) Crown 2021

\begin{abstract}
Many authors blame postmodernism and studies on Sociology and Anthropology of Science (Science Studies) for the rise of relativism and anti-science movements. Despite such criticism, Science Studies have always been concerned with the construction of the common world (a shared reality), while the anti-science movement goes in the opposite direction, denying science to defend economic and political interests of specific groups. In this sense, the post-truth movement is part of a political agenda and therefore science education will not be able to face the dilemmas of such scenario unless it takes a clear political stance. Thus, our objective is to present a discussion on why we should trust science as well as what it means to trust science precisely from the so-called ontological turn of science studies. We argue that, based on this sociological framework, it is possible to recognize the value of science as a community capable of producing networks and actors that mobilize the world and that respond to day-to-day problems. Next, we discuss the fact that trusting in science does not mean blind trusting specialists. It is necessary to increase the participation of different actors in the construction of the common world, especially by calling into debate those who were made invisible in the process of colonialism. Finally, we argue that recovering confidence in science is a political process, in a way that public opinion can only changed by politically organizing the field of science and science education.
\end{abstract}

\section{Introduction}

Five years ago, in 2016, the Oxford dictionary declared "post-truth" as the word of the year, defined as "an adjective relating to circumstances in which objective facts are less influential in shaping public opinion than emotional appeals" (Oxford Dictionary, 2016). This choice only revealed a perception that, for some time, had been shared by many communities, that there was (and there is) a growing movement of denial of knowledge

Nathan Willig Lima

nathan.lima@ufrgs.br

Matheus Monteiro Nascimento

matheus.monteiro@ufrgs.br

1 Graduate Program in Physics Education, Universidade Federal Do Rio Grande Do Sul, Av. Bento Gonçalves, 9500, Building: 43124 Physics Institute, Campus do Vale, RS, Porto Alegre, Brazil 
established by the scientific community, as well as of denial or even alteration of clearly recognized historical or social facts (Allen et al., 2020). What at first seemed isolated and even grotesque, like the flat-Earth or anti-vaccine movements, became a fundamental element in the political trajectories of different countries: the election of Donald Trump in the USA and the BREXIT, as well as the public discussion about climate change, are just a few examples of political events that have been affected by the avalanche of fake news and distorted narratives promoted by social networks (Latour, 2017a).

While the confront about the origins of climate change (and necessary polices to contain it) addressed an apparently distant future, the COVID-19 pandemic presented extraordinary and unexpected challenges, demanding fast, organized, and collective actions. In 2017, many scientific studies had already pointed out to the possibility of a new pandemic and drawn attention to the need of a global, integrated scientific solution (Lakoff, 2017). This has been neglected by governors despite the scientific value of such studies, especially due to the difficulty in imaging such catastrophic scenarios (Hurlbut, 2017). In 2020, a study showed that politically polarized countries (such as USA and Brazil) had the worst response to the pandemics (Jasanoff et al., 2020). In this sense, the pandemic has made evident that science trust as well as how society should answer to collective danger is something to be politically decided now (in the present). It cannot be postponed anymore (as it seemed in the case of climate change). Pandemics brought a sense of urgency to an agenda that has been in the public sphere for decades now.

We live in a society where technological development and scientific knowledge are intertwined with basically all of our day-to-day practices-almost all work requires computers and cell phones, eating habits rely on food that go through industrial processes, same for medicines, transportation, and so on. In other words, these hybridized practices co-create nature and society (Jasanoff, 2004, 2015). Intentionally denying specific facts to promote certain political values, in some cases, implies denying scientific knowledge and attacking scientific communities when they do not meet the interests of the groups in question.

For example, to support the discourse that we can continue to grow economically without restrictions and ignoring the debate on fuel sources, it is necessary to attack the scientific communities that point to climate change and to the profound environmental impacts that our economic system has caused. To continue destroying the Amazon rainforest for agrobusiness and logging, it is necessary to attack scientists who show the progress of fires in Brazil; to defend the end of social isolation and to heat up the economy, it is necessary to disqualify the work of universities that point out the need to maintain preventive measures. The question of "post-truth," despite raising philosophical questions (Mcintyre, 2018), is not and has never been a purely academic, abstract question, a consequence of the epistemological discussion.

Some authors accuse Science Studies ${ }^{1}$ of promoting relativistic visions, originating even what was known as "Science Wars" (Gross \& Levitt, 1994; Sokal \& Bricmont, 1998). Despite of that, the recent episodes have reinforced that Science Studies cannot be associated to the post-truth agenda since they have different political commitments (Jasanoff \& Simet, 2017; Latour, 2017a).

\footnotetext{
1 Science Studies is a broad term used to designate the field of sociology that studies science. It is close to STS (Science, Technology and Society) and it is often associated to post-modernism.
} 
In this work, we have three objectives. The first objective is to discuss that Science Studies and, more specifically, Bruno Latour's theoretical framework ${ }^{2}$ (considered by many as an enemy of science) actually suggests that we should trust science. By doing so, we hope to reinforce that discussing politics in science does not mean to devalue the latter. Our second objective is to expand the discussion on what trusting science means-emphasizing that this does not mean to blind trust specialists. And as a third objective, we expect to present a concrete programmatic agenda to recover confidence in science, mobilizing different social groups in the construction of a more just and egalitarian world while also emphasizing the role of science education in this process.

The paper is structured as follows: in Sect. 2, we briefly present a historical context for the emergence of Science Studies to then outline Latour's theory in this field, stressing how it points to the necessity of trusting science. In Sect. 2, we answer the following question: according to theoretical frameworks in the context of Science Studies, why should we commend and rely on scientific knowledge? Subsequently, in Sect. 3, these are the questions to be answered: within the adopted theoretical perspective, what does it mean to trust sciences? What is the role of society in general in decision-making? And, above all, how to accommodate the points of view of other groups (usually invisible in the process of colonization) for building the world? In Sect. 4, we mobilize the previous discussion to answer the question: what is the role of science education in the contemporary (post-pandemic) scenario?

\section{Why Should We Trust Science? A Justification Based on Science Studies}

In order to discuss Science Studies and Bruno Latour's contribution to the matter of trust in science, we will briefly introduce the historical context for the emergence of Science Studies (Sect. 2.1), then a brief but broader discussion on science studies (Sect. 2.2), an overview of Bruno Latour contributions (Sect. 2.3), and a final deliberation about why science studies should not be associated to post-truth (Sect. 2.4).

\subsection{From Sciences to Science Studies}

The birth of modern science ${ }^{3}$ is above all marked by the search for a methodological rigor that can provide means to determinate an absolute truth and to identify reliable knowledge (Latour, 1999). This conception of science lasts at least until the nineteenth century, when, as an example, Pedro Américo (1869) suggested that scientific knowledge is evident to reason and that it cannot be contested after determination. We may say that, in this period, there is the predominance of what we may call absolutist views, according to which there is a clear and absolute break between science and non-science. Most absolutist thinkers agree on the need to search for absolutely reliable knowledge, but they do not agree on

\footnotetext{
2 We chose to present Latour's framework because he is one of most controversial and popular Science Studies scholar, whose theory actually provides an interesting philosophical framework to validate and favor science.

${ }^{3}$ In this work, e use popular characterization as in Americo (1869) and Whitehead (1925), according to which it is understood that modern science begins in the sixteenth and seventeenth centuries with works by researchers such as Galileo, Kepler, Descartes, and Bacon.
} 
how to obtain it. This disagreement appears very clearly, for example, if we compare the emphasis that Descartes and Bacon give to reasoning and empiricism.

Alfred Whitehead (1925), an author who strongly influenced the work of many scholars in the field of Science Studies (for instance, Bruno Latour (1999) and Isabelle Stengers (2011, 2020), claims that what marks the scientific movement in the sixteenth century, more than the scientific knowledge itself and the technologies derived from it, is the mentality proposed by this movement, which passionately embraces the notion of fact: "This new tinge to modern minds is a vehement 'and passionate interest in the relation of general principles to irreducible and stubborn facts" (Whitehead, 1925, p.3). In addition to the central role of the notion of fact, modern science is marked by a search for universality: "Another contrast which singles out science from among the European movements of the sixteenth and seventeenth centuries is its universality. Modern science was born in Europe, but its home is the whole world" (Whitehead, 1925, p.4).

As Latour $(1993,1999)$ points out, different philosophical currents defended the absolute reality of facts as well as the universality of scientific knowledge in different ways. However, all of them are supported by an insurmountable chasm between two distinct and irreconcilable ontological poles, nature, and society. Just to mention two examples, Descartes considered that such an ontological disjunction manifests itself in the separation of res extensa and res cogitans; for Kant, it is the isolation of objects-in-itself and the transcendental ego that manifests the same separation. The question that naturally arises (and for which different philosophical currents have given different answers) is how is it possible to guarantee absolute certainty about nature, if we are forever stuck in our subjectivities (Latour, 1999)?

In the recent epistemology, an answer can be sustained with the so-called correspondence theories (Popper, 1963). According to this view, nature can be thought of as a set of objects (since they are not subjective) and facts, whose existence occurs in an absolute and autonomous way. The essence of everything that exists in the natural world was not created by mankind, but by nature itself. Whenever an utterance (an element of discourse, which is therefore social) is made about nature, one can confront it with the natural world. If some correspondence is attested, it is said that the statement is a form of knowledge; otherwise it was nothing more than a belief or a fetish (Latour, 1999).

Such an ontological-epistemological scheme underlying the modernist worldview was not limited to academic debate. The passionate belief in facts and the universality of scientific knowledge has shaped the most different spheres of modern society (Capra, 1982; Devall \& Sessions, 1985; Santos, 2008). More specifically, some authors understand that the objectified notion of nature, in which it can be seen as independent from the social world, is consistent with other objectifying views of the world, such as racism, capitalism, and patriarchy (Santos, 2019). In this sense, the fusion between capitalism and science, supported by a reductionist conception of reality, has been the driving force behind industrial revolutions, technological advance, and the consolidation of the consumption society. Consequently, such a merge is the source of many ecological and sociological problems that we face today. ${ }^{4}$

In the beginning of the twentieth century, this epistemic and political view was corroborated by the profound transformations that society was facing, with technological advancement, increasing urbanization, and the advance of the capitalist system. These

${ }^{4}$ A similar discussion can be found in Foucault (2008) 
transformations are consistent with the consolidation of thermodynamics (and its thermal machines) and the electromagnetic theory (with the lighting and then the communication system), for example. This placed a great confidence in scientific knowledge and in its ability to promote social well-being, forging the common-sense conception of science, according to which science is neutral, purely logical (non-creative), developed by geniuses, as if scientific work was a perfect mirror of reality (Chalmers, 1978).

On the other hand, as Lima et al. (2019) points out, it was also in the twentieth century that the public image of science, as well as the epistemological and social ideals that it inspired, were placed under suspicion. In particular, studies on the environmental impacts of modernist progress (Carson, 1994), as well as the evident danger of geopolitical conflicts revealed that science could not be considered a neutral or harmless practice. During this period, different studies started to point out the social, political, economic, and non-rational aspects of science-some of which became known as the general label of postmodernism (Mackenzie et al., 2014). Also, Thomas Kuhn's (1996) The Structure of Scientific Revolutions ${ }^{5}$ deeply contributed to the formation of a sociological understanding of science, leading to the formation of a new field: Science Studies (Edge, 1995).

\subsection{General Considerations About Science Studies}

Science studies, or sociological studies of science, cannot be considered a homogenous filed but a set of theoretical and methodological perspectives that try to describe and explain science. Collins (2002) divided Science Studies in three waves. The first wave encompasses the sociology of scientists, describing the non-neutrality caused by financial funding and political disputes, for example. The description of scientific field by Bourdieu (1976), for instance, could be put in this first wave. The second wave, however, went much deeper into the sociological path, searching not only for a sociology of scientists but also a sociology of scientific knowledge (SSK). In this wave, we can find the Strong Program of Sociology (Bloor, 1996) and the Anthropological studies of the Laboratory (Woolgar, 1982). Finally, the third wave is directed toward the problem of experts and their role in society (Collins \& Evans, 2017).

The second wave is where we find the most radical sociological concepts, which triggered the Science Wars. One in particular is the Principle of Symmetry (Bloor, 1996). This principle states that all utterances (either true or false) should be explained by social causes. In other words, when some controversy is solved, we should not assume that scientists achieved some truth or that a natural fact solved it; we need social explanations to why the controversy was solved. This proposition by itself can be considered relativist, ${ }^{6}$ as it deals with truth and falsehood in symmetrical terms.

In the same second wave, there is also what became known as the "ontological turn," i.e., a set of works and propositions that challenged the metaphysical scheme that separated nature and society absolutely. Some examples are Bruno Latour (1999), Knorr-Cetina (1981), and Isabelle Stengers (2003a, 2003b). These authors argued that there is not only one truth nor only one reality, a conception that is also shared by decolonialist anthropological studies (Castro, 1996).

\footnotetext{
5 Originally published in 1962.

${ }^{6}$ Relativist is the opposite of absolutist.
} 
While many studies on science education have been impacted by these sociological discussions (Lemke, 2001; Tolbert \& Bazzul, 2017), many are the authors who have blamed these movements for the post-truth era in which we live. As Mcintyre (2018) suggests, post-modernism is a ground for post-truth. According to the author, post-modernism can be associated to two theses: first, that there is no objective truth and, second, that everything considered truth is simply the product of political action. Also, Mcintyre (2018) states that post-modernism went too far when social constructivists (such as the Strong Program) started to describe science as a social construction, and he mentions Bruno Latour as an example of a post-modernist author to be criticized. Mario Bunge (1999), for instance, claims that Latour describes science as a collective invention of truth (Bunge, 1999, p.32) and that scientific community is depicted as a political committee (Bunge, 1999, p. 297). Also, Sokal and Bricmont (1998) claim that Latour's discussion on physics is full of mistakes and misconceptions about Einstein's relativity.

Assuming that Latour was a protagonist in these science wars and that he has been much blamed due to the genesis of social constructivist conceptions about science, we are going to explore his ideas closer. More specifically, we will discuss how Latour's framework has actually denied Bloor's Principle of Symmetry, which allowed him to defend science in the contemporary world.

\subsection{Latour's Contribution to Science Studies and to the Matter of Science Trust}

Latour became widely known by his contributions to the Laboratory Studies (Latour \& Woolgar, 1986). In this work, Latour claimed that scientific facts are social constructsreason why he is still remembered as a relativist. Along the years, however, Latour has been explaining and clarifying what social means. According to him (Latour, 2005), social is everything that is relational - that encompasses relations or that is a result of relations. Thus, differently of many other sociologists that consider social aspects to be human aspects, when Latour says that scientific facts are social, he means that they are produced by relations of humans and non-humans (Latour, 1999).

This subtle difference in Latour's definition of social is enough for him to reject Bloor's Principle of Symmetry. According to Bloor, truth and falsehood can be explained from social causes (human productions). To Latour (1993), what we call nature (scientific facts) and what we call society (human productions) results from the networks created by humans and non-humans, so scientific facts cannot be explained by society alone. Latour calls this idea the Generalized Symmetry, which is represented in Fig. 1.

One could still say that Latour's view is relativist as it considers nature a creation. However, Latour $(1993,1999)$ argues that different networks mobilize different realities, with different extensions and abilities of affecting us. He uses the example of a network of fermentation microbes, which should be much wider than a network of spontaneous fermentation (which was rejected by scientific community after Pasteur's studies), since many technologies and products are involved in biological fermentation. So, although there may be people who still defend spontaneous fermentations, we cannot say that this reality is equivalent to biological fermentation.

Networks are what sustain reality. The wider the network, the greater is the reality. To Latour, we can hierarchize different realities and decide which one is more real (Latour, 1999). Thus, in the matters of climate change, vaccines, and social isolation in the pandemics, there are networks wider and more real than others-it is not possible, according to 

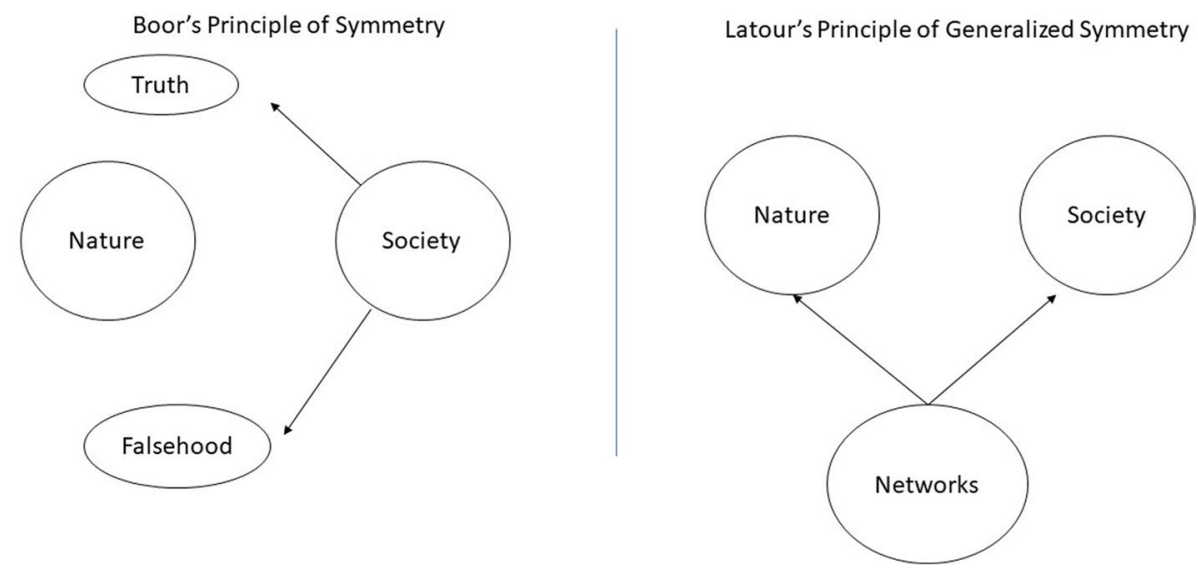

Fig. 1 Representation of Bloor's Principle of Symmetry and Latour's Principle of Generalized Symmetry. Adapted from Latour (1993)

Latour, to make them equivalent. In this sense, post-truth is not about truth versus falsehood, but about a very stable and wide network against a small and unstable network.

From this perspective, we can move away from the concepts of absolute facts and that of a universal objective science. Knowledge and science are the result of an intense process of articulation and translation between humans and non-humans, which distances us from epistemological absolutism and, most importantly, from an ontological vision that places nature as a transcendental entity. However, different collectives or groups support different networks and so different realities—which allows us to hierarchize such realities, avoiding relativism.

Thus, unlike what Latour's critics usually claim, his social constructivism does not imply a relativist position. According to Latour (1993, 1999), we cannot reduce reality to human volition, neither as a mechanism of discourse nor to play political games. Reality is the world established through the collectives of humans and non-humans; it is at the same time natural, social, and discursive (Latour, 1997). Latour's rejection of the strong program of sociology resulted in a many-pages-long paper written by David Bloor (1999), entitled Anti-Latour, where the father of the Strong Program criticizes Latour's ideas. Therefore, we can definitely say that Latour's framework departs a lot from the hegemonic assumptions of the Strong Program and Mcytire's views on post-modernism.

In general, an important characteristic of scientific production is that it is the result of an intense network of articulations, which tries to accommodate different theoretical elements, proposed by humans, and results obtained from experiments in laboratories, which are independent of human volition. In relation to typically modern problems where scientific elements are highly hybridized, it is natural that the scientific community itself presents the best articulated propositions. If all realities were equivalent, it would not make sense to defend a better view to solve any public problem. However, according to the vision presented here, problem-solving requires networks capable of acting and modifying the material reality that surrounds us. In this sense, the scientific network presents itself as a good candidate to contribute to these issues. In a recent interview, Latour has stressed the necessity of taking back the respect for science: 
We will have to regain some of the authority of science. That is the complete opposite from where we started doing science studies. Now, scientists have to win back respect. But the solution is the same: You need to present science as science in action. I agree that's risky, because we make the uncertainties and controversies explicit (VRIEZE, 2017).

This discussion has an important impact for science education. Latour understands that post-truth is a situation in which two networks compete for the attention of the public sphere as if they were equivalent, but the fact is that one network is much wider and stable than the other. According to Lima et al. (2019), one of the problems we are confronted with is that scientific facts are presented to society (in educational contexts also) as black boxes (Latour, 1988). So, whenever a community wants to defy a scientific explanation, it also presents a new black box. The public cannot verify all explanations, so it gets divided. One possible way to avoid this post-truth is to open science black boxes and show people all the network that is associated to a certain scientific claim. Only networks wider and more stable than that should be accepted to defy the scientific claim. In this sense, science education must be concerned in opening "scientific black boxes," showing science in action (Lima et al., 2019).

\subsection{Why Are Not Science Studies Related to Post-truth?}

The recent political situation suggests that the question of trusting in science goes far beyond mere academic debate (although, as Latour (2004a) points out, politicians have appropriated elements of this discussion for their own purposes) and reveals the interests of specific groups behind such propositions (Angell, 2004; Kleinman, 2003; Oreskes \& Conway, 2010) ${ }^{7}$.Thus, we understand that there is a crucial difference between science studies and what we see today.

To an extent, such academic studies point to the need to build a more egalitarian, socially and cognitively just world, in order to accommodate so many different points of view. The anti-science movement that we see today goes in the exact opposite direction. It denies the need for economic changes to make the world possible to live in for everyone; it denies the need for vaccines and protective measures to guarantee life for all, and it bets on an economic model that only widens inequalities and continues to reinforce necropolitics in peripheral countries (Mbembe, 2019). The post-truth and the denial movements make the construction of a shared reality unfeasible, betting on the expansion of social inequalities (Latour, 2017a). To associate these two movements (science denial and postmodernism) for simply not adhering to epistemological absolutism is a mistake.

In the current context, we live in a borderline situation. Studies on climate change have shown the significant anthropogenic changes on Earth, motivating the suggestion of the name of the current geological period-Anthropocene (Latour, 2017b). In addition, the COVID-19 pandemic has demanded a series of efforts reinforced by scientific results worldwide to mitigate the damage caused by this disease that undoubtedly affects different social groups differently (Santos, 2020). In other words, science is a fundamental factor in

\footnotetext{
7 It should be noted that the studies brought by these references point to cases in which groups composed of scientists worked to confuse public opinion regarding stabilized themes and already widely accepted in the scientific community
} 
solving contemporary problems. In this sense, science and science studies converge, aiming to guarantee a common world.

\section{How to Trust Science? ${ }^{8}$}

As discussed in the previous section, it is possible to escape the modernist ontological order, adopting Latour's Generalized Principle of Symmetry. Such a view implies the recognition of co-existence between different realities - which, on the one hand, allows us to escape from epistemological absolutism but, on the other, allows us to rank the different propositions according to the networks that articulate them. Therefore, Latour's theory allows us to move away from a radical relativistic view.

Nonetheless, this theoretical positioning poses new questions: does it mean that recognizing that propositions can be hierarchized and that science is able to articulate such networks, accommodating a great multiplicity of human and non-human propositions, implies that scientific community alone solves socio-scientific or socio-technical problems? Should we blind trust experts so that they can tell us what to do? Does recognizing that science is a reliable source of propositions mean that we can treat socio-scientific problems simply as scientific problems? Our answer to all of these questions is no. Following this path, we enter the second point of this article: what does it mean to trust science and how (or to what extent) should we trust science?

This is obviously not a recent problem. As Latour (1997) points out, the problem of the relationship between the epistemic status of knowledge and the decision-making regime on public matters already appears in Plato. Latour (1997) remembers us that, according to Plato, defending an absolutist epistemology implies defending against the democratic regime. After all, why do we need the multitude of ignoramuses when we have the knowledge of scientists? Rousseau (1750) is yet another example of philosopher who questioned whether specialized knowledge could increase people's happiness, coming to the conclusion that it was better if it did not depend on science. The same issue is addressed by Feyerabend (1982). In the field of science studies, it is understood that the discussion about the role of specialists in society forms the so-called third STS wave (Collins, 2002, 2018; Collins \& Evans, 2017, 2019; Collins et al., 2017, 2020).

As we will discuss in this section, although scientific and technological knowledge is fundamental for solving contemporary problems, such problems can in fact only be solved if there is an engagement of the population. It is necessary that citizens see themselves as active agents in the process of building society and the world, an ideal defended by many authors in the field of Science Education (Alsop \& Bencze, 2014, 2020; Bencze, 2017; Hodson, 1994, 2003).

In the context of the theoretical framework that we are presenting, some considerations need to be raised. The first is that the process of articulating propositions and disputes between different networks is not an abstract process, but it takes place in material and concrete conditions-depending on relationships between humans and non-humans. Latour (1999), for example, narrates the symmetry between Frédéric Joliot's findings on neutrons

\footnotetext{
${ }^{8}$ In this section, we will keep restricted to sociological discussions. However, there is important discussion in the filed Epistemology that also points out why to trust science. Specially, the philosophy of science practice, which discusses the role of evidence (Cartwright, 2017), how agreements and model are built in practice, as well as other relevant topics to this matter (Chao \& Reiss, 2017).
} 
and the articulations that he had to do with politicians to carry out his nuclear project. Science development is not decided only by non-humans nor only humans themselves can manage to define new propositions. There is an intense social (relational) work in heterogeneous collectives that allow such a process of stabilization.

Thus, propositions that emerge victorious and stabilized are those that survive cosmopolitics or a process in which humans and non-humans interact to build a possible common world ${ }^{9}$. As Latour puts it:

COSMOPOLITICS: An ancient word from the Stoics to express an affiliation to no city in particular but to humanity in general. The concept acquired a deeper meaning through its use by Isabelle Stengers to mean the new politics that is no longer framed inside the modernist settlement* of nature* and society*. There are now different politics and different cosmos. (Latour, 1999, p.306).

It is also important to mention that he uses this term under the influence of the Belgian philosopher Isabelle Stenger (2003a, 2003b, 2018), who, according to him,

has reinvented the word by representing it as a composite of the strongest meaning of cosmos and the strongest meaning of politics precisely because the usual meaning of the word cosmopolite supposed a certain theory of science that is now disputed. For her, the strength of one element checks any dulling in the strength of the other. The presence of cosmos in cosmopolitics resists the tendency of politics to mean the give-and-take in an exclusive human club. The presence of politics in cosmopolitics resists the tendency of cosmos to mean a finite list of entities that must be taken into account. Cosmos protects against the premature closure of politics, and politics against the premature closure of cosmos. For the Stoics, cosmopolitanism was a proof of tolerance; cosmopolitics, in Stengers's definition, is a cure for what she calls "the malady of tolerance." (Latour, 2004b, p.454).

For Latour different collectives arrive at the same entities that exist in the world through cosmopolitics, which also means that it is through cosmopolitics that we achieve a common world. Thus, adopting the metaphysical perspective discussed in the previous section, it must be understood that the common world is not something transcendental and that can be used as an explanatory factor to end controversies but is rather what emerges from the cosmopolitical process. The common world is a possible world, never finished, never closed, that arises from the tensions and articulations of the cosmopolitical process. For a proposition to become part of this common world, to become a matter of fact, it needs to be able to get surrounded by a network of humans and non-humans to settle. It therefore needs to be a matter of concern ${ }^{10}$.

\footnotetext{
${ }^{9}$ Because different networks produce different realities. To Latour, we do not live a priori in the same world. Only when different collectives agree about the validity of the same networks, we can share one single and common world.

10 Although Latour appropriates the term from Stenger's reflections, there is an understanding that the meaning given by Latour differs to some extent from the original view (Blaser, 2016). While Stengers (2018) emphasizes the importance of putting under suspicion the obviousness of which common world should be sought and which methods are useful in the construction of the common world, adopting the stance offered by the conceptual character of the idiot, proposed by Deleuze. Latour (2004a, 2017a), on the other hand, has emphasized the importance of urgently accommodating different points of view in building a common world before the consequences of climate change make this process too late.
} 
This not only means that scientific knowledge affects social relations, but that it results from an intense political process. Recently, we carried out a discussion about the initial stage of the pandemic, highlighting epistemic and political entanglements (Moura et al., 2021). In such a cosmopolitical process, a question that must be taken into account is who are those who participate or have the right to participate in the construction of the common world? Or, in other words, who decides what is matter of concern? De la Bellacasa (2011) argues that, in general, there are characters who are excluded from the process of building the common world, whose concerns are invisible to the scientific community (a discussion that is ignored by Latour). So, first of all, if we really want to build a common world that is inhabitable by all, there should be mechanisms throughout the cosmopolitical process so that the concerns of more actors are made visible. That is why it is necessary to shift the discussion from matters of concern to matters of care (de la Bellacasa, 2011).

In addition, a second point to be made relates to the very nature of decision on public affairs. While science can say with great confidence what is the chemical composition of the atmosphere and what will be the impact of the use of a certain fuel, the decision on whether certain sectors of the economy responsible for the subsistence of countless families should cease to exist in order to achieve a better environmental future is to be made by politicians. While science can tell how much of the Amazon burns down in Brazil daily, politicians need to decide how much they want to slow the advance of agribusiness, one of the main economic sectors in the country and that guarantees the government the possibility to buy vaccines to save lives. While science can tell what is the impact of social isolation in the pandemic, politicians have to decide whether to apply it and affect the economy of a country where half the population is in a situation of food insecurity.

In summary, although socio-scientific problems depend heavily on information provided by science, which clarifies important factors to be taken into account, the final decision extrapolates the purely technical issue, involving economic demands, political commitments, ethical, and moral decisions, among others. This problem leads to the question of double responsibility discussed by Bakhtin (1999), according to which, in our concrete actions, we respond to two different spheres of reality. We respond to the world of culture (like the world of science or arts), but we also respond to the world of life, or our moral responsibility. Governments and citizens must respond to the information provided by science with their actions, but they also need to respond to their moral and political commitments.

The recent movements to regard socio-scientific problems, such as those caused by the pandemic, as purely technical questions are certainly a cause of concern, as they suggest that specialists should have all the answers to these problems. The answer of science is just part of the bigger picture that should inform us about the construction of the common world, and the final decision should involve people's shared values and objectives in building this world. Again, scientific networks may provide the more extensive and stable reality. We should listen to the scientific consensus about our contemporary problems at the same time that the final decision must take values from the different social groups into account. The scientific community is expected to inform the decisions to be made, but the decision also needs to accommodate the views of different groups interested in building the common world.

The questions that follow this reflection are straightforward: which groups will be heard and what values will be taken into account? Should we accommodate the views of antivaccine groups? Should we accommodate the views of flat-earthers? Should we listen to science deniers in general? Our answer is no. If we accepted that any group could claim a participation in the cosmopolitical process and assume that any point of view should be 
acceptable in that process, we would just be escaping the dangers of authoritarian absolutism to dive into an immobilizing relativism.

We argue that it will be necessary to build the articulation between different communities, knowledges and methodologies, in what Boaventura de Sousa Santos calls an ecology of knowledge (Santos and Meneses, 2009), i.e., the articulation of knowledges that points to the construction of a just world. It is based on this ecological proposal that we highlight the potential of the pedagogy defended by Paulo Freire (2018), according to which the education process is built with the community, based on their local and concrete issues. Not only that, but the very solution to these problems can still be informed by science while being made according to other worldviews that are more ecological in essence, such as that advocated by the indigenous leader Ailton Krenak (2020a, 2020b).

Candidates to participate in this ecology, understood as an accommodation from different points of view about the world, must meet a criterion of "demarcation". This criterion is rather epistemic-political, and is not purely epistemic as envisioned by Popper (1963). The groups and points of view that are accommodated in the ecology of knowledge must be those committed to the construction of the common world and to the promotion of social and cognitive justice ${ }^{11}$ (Santos, 2019).

Thus, we understand that trusting science demands more people to be part of science and public decision processes. The scientific community will not regain society's trust as long as it does not answer to society's deep concerns. And one way for that to be possible is by creating more spaces of dialogue and communication. We need to articulate communities around matters of care, in order to ensure a habitable Earth for everyone. Only knowledge and communities committed to these values can contribute to the urgent construction of a common world. Santos (2019), for instance, proposed the concept of pluriversity in opposition to university. In a pluriversity, there is space for different communities to dialogue and thus to build a common world. Science could greatly contribute to these spaces.

\section{How to Act in the Post-pandemic World? What Is the Role of Science Education in the Construction of a Common World?}

Having answered the initial questions of why and how to trust science, in this section we aim to introduce a more action-oriented discussion, reflecting on the role of science education in the post-pandemic world. At the beginning of the twentieth century, the American sociologist Robert Merton, based on the study of science, technology, and society in seventeenth century England, described the religious, professional, economic, and institutional conditions for the scientific and technical revolution that occurred in the origin of modern science (Merton, 1938). Even recognizing the numerous texts on science prior to his work, Merton's thesis is often considered to be foundational for the sociology of science. His work is important because he contributed significantly to the establishment of a differentiationist perspective, which is concerned with the institutionalization of science, albeit maintaining the separation between cognitive and social contents or, in other words, the division between sociology and epistemology of science (Shinn and Ragouet, 2005).

\footnotetext{
11 To Santos (2019), it is not enough to just allow everyone to access scientific knowledge and technologies in order to have justice. It is also necessary to consider knowledges that have been annihilated in the process of colonization-what he calls epistemicide.
} 
Reflecting on the current scenario in which confidence in institutions is absolutely undermined, as it was seen with the invasion of the US Capitol shortly after the defeat of former president Donald Trump in the elections, it is worth asking how we can convince people to follow the idea of a common world with cognitive and social justice. This is an issue that has to be addressed by taking into account not only agents and their uniqueness but also the collective intersubjectivity. For example, it seems unlikely that scientific dissemination by itself will be able to change a person's opinion on the effectiveness of vaccines, the anthropogenic effect on global warming or the legitimacy of the American electoral process ${ }^{12}$. Discussing the role of science in the classroom from the perspective of science teachers on problem-solving is also not enough to convince students about these issues in any level of education. It is then necessary a broader perspective that considers all the dialogicity present in the communication and convincing processes.

Therefore, we propose to look at the psychology of persuasion in order to find a perspective that helps us develop a proposal for scientific education that is able to persuade and convince people. Petty and Cacioppo (1986) present a theory to explain the degree of influence of persuasive communication on changes in behaviors, feelings, beliefs, and attitudes - the Elaboration Likelihood Model of Persuasion (ELM). For the authors, there are two possible ways for people to evaluate information and be convinced of something. The first, called the central route, is that linked to epistemic, rational, and cognitive aspects, through which people get involved with scrutiny and analysis of information (Petty and Cacioppo, 1986).

We understand that both the traditional teaching of science, as well as many of the proposals currently considered innovative, point towards persuasion, suggesting that beliefs occur based on the "quality" of information. Many discussions on science education, and which for a long time contributed to the qualification of the field, operate in the same line. The second possible form of persuasion, which is directly related to the fact that people believe that the elections were rigged or that the earth is flat, is one that does not depend only on the person's ability to assess the veracity of the information or its quality but also on the relationship that this person establishes with the source of the information (Petty and Cacioppo, 1986). For example, Donald Trump's voters did not evaluate the coherence and validity of the arguments that votes were poorly counted or cast down but were instead convinced that they did and so invaded the Capitol. This conviction occurs, in general, through trust, fascination, or respect for the emitting source. This second type of persuasion is called the peripheral route.

We understand that teachers in all areas, and not just science, need to work with the two routes of persuasion, but especially from the second, historically disregarded from pedagogical discussions and even research in education. This finding highlights the need for an improvement not only in the specific space of the classroom, but also in the communication between scientists and society. That is to say, it is not enough to assume that the simple disclosure of scientific evidence or information, whatever be the rigor or clarity of the information issued, will be sufficient to convince the population to adopt a certain behavior. This has been studied as affect in science education (Alsop, 2005, 2015; Alsop \& Watts, 2003). People have to be affected, mobilized, to feel sensible to the matters that are presented-this is a crucial part of building a common world (Latour, 2017a). It must be

\footnotetext{
12 Not only is the process of scientific dissemination inefficient in affecting public opinion, but also, as Paulo Freire (2013) argues, it starts from the assumption that science or academia created the world alone, and we only need to deliver it to people, while what we want is the collective construction of the world.
} 
said that acting through the second route of persuasion, as well as qualifying communication processes to convince people, does not mean manipulating them in a negative sense. We understand that there is a difference between convincing and manipulating. No matter how close they are in terms of the final result, which would be the change of an attitude, we consider that, unlike persuasion, manipulation can cross moral and ethical boundaries to achieve a goal.

In this context, scientific education needs to take into account this subjective relationship with knowledge, understanding the dialogicity of communicative processes. This means that we cannot think of science education as just what happens inside the classroom. We need to think about it in the great public debate. Furthermore, it is necessary to recognize that different individuals trust institutions, groups, or people in different ways, which is reflected in the acceptance or rejection of information. For this reason, it is essential to articulate communities that can become reliable enough to increase the likelihood of convincing individuals. Articulation, in this sense, means strengthening existing political institutions, such as scientific associations in the most different fields of study, and creating mechanisms for dialogue (instead of simple dissemination) among the society.

In the case of science education, for example, we cite the European Science Education Research Association (ESERA), the International Organization for Science and Technology Education (IOSTE) and the International Group of History and Philosophy of Science Teaching (IHPST) as institutions with the potential to act on the peripheral route of convincing through the strengthening of dialogue with other groups. That is, as we assume that there is a constant discursive dispute over truth (Foucault, 2008) and that the ways of knowing and representing the world (both nature and society) are inseparable from the way that we choose to live in it (Jasanoff, 2004, 2015), it is essential to take into account the role of these communities and institutions in defining what can be called socio-cultural knowledge (Fischer, 2019). So, to answer the question proposed at the beginning of the section, we are saying that the most effective way to convince people to follow the path of the common world and cognitive and social justice is through the establishment and strengthening of these communities articulated around the goal of building a common world that is socially and cognitively just.

The same stance can also be taken in the educational context. Professors of scientific subjects need to be aware of the fact that the ideas disseminated in their classes will interact with socio-historically located subjects, each with different social origins and different socialization processes. This requires these teachers to develop a dialogical education (Freire, 2018), centered on the horizontality of knowledge and respect for different points of view. Based on the proposals for a socio-political turn in science and mathematics education (Hodson, 1994; Gutiérrez, 2013, Tolbert and Bazzul, 2017; Moura et al., 2021), we defend an educational rupture in terms of curriculum, reducing the emphasis on specific content and adopting local socio-scientific criteria. Similar to what has already been discussed in other social spaces (Alsop and Bencze, 2014; Bencze, 2017; Sjöström and Eilks, 2018), our proposal moves towards not only valuing, but also thinking about education and sciences from the uniqueness of the different contexts.

This vision of education is in line with the speeches and proposals of the Brazilian pedagogue Paulo Freire. Freire (2018) thinks the pedagogical process from the articulation of what he called "culture circles," which are formed by teachers from different areas, people from the local community and students. In the meetings, members are united towards a common world, with dialogues and critical reflections about it. The "circle" is not a place 
to teach, but to learn in reciprocity of consciences (Freire, 2018). Meetings start with a survey on the themes to be studied, looking for local problems and contradictions, that is, there is no prior content, just everything is built upon a horizontal dialogue between people, or, more specifically, in an ecology of knowledges (Santos and Meneses, 2009).

Finally, we list the measures that we believe that need to be taken to restore confidence in science and science education:

- As the process of trust takes place in the sphere of public debate, a first step is to strengthen institutions that can tension the political scenario and public opinion, such as IHPST, IOSTE and ESERA. Strengthening means increasing the number of members and partner institutions.

- The strengthening of these communities serves, first of all, as a means to express matters of care and matters of concern, to stabilize practices, to share experiences, to contribute to the formation of researchers and educators trained and interested in building the common world, and to promote social justice. Therefore, it is necessary to strengthen events, training courses, forums and other spaces for dialogue.

- The strengthening of these communities serves, in the second place, to tension public debate, through digital media, dialogue events with the different sectors of society, pressure on political institutions to value science and education.

- In the classroom, the first necessary measure is a curricular break, moving from technical themes to socio-scientific issues.

- The decision on which socio-scientific issues should be addressed is not imposed by the teacher or by a group of experts but is collectively constructed by the teacher and the school community, based on concrete problems and concerns of the community as defended by Paulo Freire.

- The construction of a solution to such questions involves recognizing information provided by science, but is not limited to it. The political and moral dimensions involved in the issues have also to be identified.

- Not only scientific knowledge but any knowledge aimed at building the common world and promoting social justice, such as the worldview of the original peoples, are welcome in this process of articulating an ecology of knowledge.

- At the end of the process, concrete actions are planned to promote the construction of the common world and social justice.

\section{Concluding Remarks}

The new coronavirus pandemic made it clear that we need to rethink the role of science in decision-making processes in all countries of the world. In theoretical terms, the spread of denialism, influenced by many public representatives, has heated the discussion on the phenomenon of post-truth. In addition to the theoretical discussion, the dissemination of fake news and factual inaccuracies about recommendations and results from scientific sources has made it difficult to control the pandemic in many countries, that is, it has a direct impact on people's health. In this scenario, it is essential to answer the question proposed by the Science and Education journal: "Why Trust Science and Science Education?". Extrapolating the proposed question, in this paper we propose to answer not only why but also how we can trust science and what is the role of science education in the postpandemic world. 
For the first question (Why), we articulated an answer based on social studies on science and technology (STS). We showed that a fundamental characteristic of scientific production is its intense network of articulations, which accommodates elements of human and non-human agents, such as theorizations and findings of laboratory experiments. This perspective seeks to move away from scientific absolutism, since it does not use an exclusively epistemic criterion to characterize scientific production. For the problems that emerge from modern life, it is natural for the scientific community to come up with better articulated propositions than those produced by other groups. Thus, the theorization that allows us to move away from absolutism shows us the way to avoid falling into radical relativism. Thus, we must rely on science because its better articulated networks allow us to establish guidelines and actions to change the real and material context around us.

On how to trust science, we discussed the issue from two perspectives. First, science takes place in a cosmopolitical process, in which a fact that becomes scientific is something that first needs to aggregate a community around itself (a matter of concern). However, to think about social problems and ensure the promotion of social justice, one must take into account who are the people who are concerned. To this end, we propose a reflection based on the concept of matter of care to defend the idea that society needs to actively engage in the process of building the common world. Second, the concrete problems that we need to solve are not only technical, but axiological, political and ethical. Using Bakhtin's concept of dual responsibility, we recognize that we are responsible not only for scientific knowledge, but for the moral and political issues that are imposed, so only a truly collective endeavor should be able to present viable paths for the construction of a common world.

As a way of thinking more purposefully, we indicate the need to strengthen scientific institutions based on the most effective dialogue with people. This recommendation stems from the need to take into account the quality of the arguments and information disseminated by the scientific community, as well as the relationship of trust and appreciation that people establish with representatives of scientific institutions. In educational terms, we reinforce the need for a rupture in science teaching as a means to reduce the emphasis on content and to unveil the uniqueness of every problem and agent.

Our work presents one among many possibilities to reestablish a common goal for all, that is a habitable Earth for future generations. The main point is to draw attention to the fact that we cannot carry on with this extractive economy that is directly related to anti-scientific attitudes observed today and that generate so much distress in the science education community. Our role as researchers is to reflect not only on our theoretical perspectives, whether philosophical, sociological or historical, but also on our ontological relation with this world. We cannot be content with new attempts of reform that serve only to preserve the status quo. A rupture is really needed, and we must start it from an ecological perspective that considers the multiple visions and worldviews of the world that we inhabit.

In summary, we can say that, in the first place, the present work aligns to different studies in the field of Science Education that also adopt a different metaphysical framework (Bai et al., 2021; Jeong et al., 2021; Stetsenko, 2008). From such a view, it is possible to recognize that science is a practice that co-produces nature and society, formed in the tension between political and epistemic clashes. Such a sociopolitical view of science and scientific education also matches that of different studies on Science Education (Gutiérrez, 2013; Hodson, 1994, 2003; Sjöström and Eilks, 2018; Moura et al., 2021).

Given this recognition, we advocate a broad curriculum reform, focused on the presentation of socio-scientific issues (Kampourakis, 2019), and the active role that students must play in the construction of the common world as well as the role of scientific education in this process of autonomy and action in the world - which is in line with the idea of activist 
education (Alsop and Bencze, 2014; Alsop and Bencze, 2020; Bencze, 2017; Bencze et al., 2020). On the other hand, we diverge from some authors (Fensham, 2002) as we do not understand that the curriculum, which presents the decision of what socio-scientific themes and contents should be discussed, should only be made by specialists (whether in the hard or human sciences). Rather, we think that it must be built as a collective, local and concrete guideline, in line with Freire's (2018) and Santos' (2019) theories. This means that Science Education needs to be able to mobilize, affect and impact people around "matters of care", which are themes that promote a more just and supportive world, backed up by an extensive network that connects different knowledge, including those scientific.

\section{Declarations}

Conflict of Interest The authors declare that they do not have any funding and/or conflict of interests and/or competing interests.

\section{References}

Allen, J., Howland, B., Mobius, M., Rothschild, D., \& Watts, D. J. (2020). Evaluating the fake news problem at the scale of the information ecosystem. Science Advances, 6(14), eaay3539. https://doi.org/10. 1126/sciadv.aay3539

Alsop, S. (Ed.). (2005). Beyond Cartesian Dualism. Springer.

Alsop, S. (2015). Affect in Learning Science. In R. Gunstone (Ed.), Encyclopedia of Science Education (pp. 20-24). https://doi.org/10.1007/978-94-007-2150-0_85

Alsop, S., \& Bencze, L. (2014). Activist science and technology education. Springer.

Alsop, S., \& Bencze, L. (2020). Editorial: Reimagining Science and Technology Education in the COVID19 Portal. Journal of Activist Science \& Technology Education, 11(2), I-IVV. https://doi.org/10.33137/ jaste.v11i2.34530

Alsop, S., \& Watts, M. (2003). Science education and affect. International Journal of Science Education, 25(9), 1043-1047. https://doi.org/10.1080/0950069032000052180

Americo, P. (1869). La Science et les Systèmes - questions de histoire e philosophie naturelle. Université de Bruxelles.

Angell, M. (2004). The Truth About the Drug Companies: How they deceive us and what to do about it. Random House Trade.

Bai, H., Bowering, S., Haber, J., Cohen, A., \& Chang, D. (2021). From ego to eco: re-orienting for processual ontology in the "Dao-Field." Cultural Studies of Science Education. https://doi.org/10.1007/ s11422-021-10028-w

Bencze, L. (Ed.). (2017). Science and technology education promoting wellbeing for individuals, societies and environments: STEPWISE. Springer.

Bencze, L., Pouliot, C., Pedretti, E., Simonneaux, L., Simonneaux, J., \& Zeidler, D. (2020). SAQ, SSI and STSE education: defending and extending "science-in-context". Cultural Studies of Science Education, 1-27. https://doi.org/10.1007/s11422-019-09962-7

Bakhtin, M. (1999). Toward a Philosophy of the Act. University of Texas Press.

Blaser, M. (2016). Is Another Cosmopolitics Possible? Cultural Anthropology, 31(4), 545-570. n. 69, p. 442-464, abr. 2018.

Bloor, D. (1996). Knowledge and Social Imagery. The University of Chicago Press.

Bloor, D. (1999). Anti-Latour. Studies History and Philosophy of Science, 30(1), 81-112.

Bourdieu, P. (1976). Le Champ Scientifique. Actes De La Recherche En Sciences Sociales, 2(2-3), 88-104.

Bunge, M. (1999). Buscar la filosofia en las ciencias sociales. Siglo ventiunoeditores.

Capra, F. (1982). The Turning Point: Science, Society, and the Rising Culture. Bantam House.

Carson, R. (1994). Silent Spring. Fawcett Publications.

Castro, E. V. de. (1996). Os pronomes cosmológicos e o perspectivismo ameríndio . Mana, Vol. 2, pp. 115-144. scielo 
Cartwright, N. (2017). Evidence in Practice. In: Philosophy of Science in Practice Nancy Cartwright and the Nature of Scientific Reasoning. Berlin: Springer.

Chalmers, A. (1978). What is this thing called science? University of Queensland Press.

Chao, H., \& Reiss, J. (2017). Philosophy of Science in Practice Nancy Cartwright and the Nature of Scientific Reasoning. Springer.

Collins, H. (2002). The third wave of science studies: studies of expertise and experience? Social Studies of Science, 32(2), 235-296. https://doi.org/10.1177/0306312702032002003

Collins, H. (2018). Are experts right or are they members of expert groups? Social Epistemology, 32(6), $351-357$.

Collins, H., \& Evans, R. (2017). Why democracies need science. Polity Press.

Collins, H. \& Evans, R. (2019). Studies of expertise and experience: a sociological perspective on expertise. In: Ward, Paul, Schraagen, Jan Maarten, Gore, Julie and Roth, Emilie M. eds. The Oxford Handbook of Expertise, Oxford Handbooks Online

Collins, H., Barlett, A., \& Reyes-Galindo, L. (2017). Demarcating Fringe Science for Policy. Perspectives on Science, 25(4), 411-438. https://doi.org/10.1162/POSC_a_00248

Collins, H., Evans, R., Durant, D., \& Weinel, M. (2020). Experts and the will of the people: society, populism and science. Cham, Switzerland: Palgrave. https://doi.org/10.1007/978-3-030-26983-8

de la Bellacasa, M. P. (2011). Matters of care in technoscience: Assembling neglected things. Social Studies of Science, 41(1), 85-106. https://doi.org/10.1177/0306312710380301

Devall, B., \& Sessions, D. (1985). Deep Ecology. Gibbs Smith.

Edge, D., et al. (1995). Reinventing the Wheel. In S. Jasanoff (Ed.), Handbook of Science Studies. Sage publications.

Fensham, P. J. (2002). Time to change drivers for scientific literacy. Canadian Journal of Science, Mathematics and Technology Education, 2(1), 9-24. https://doi.org/10.1080/14926150209556494

Feyerabend, P. (1982). Science in a free society. Verso.

Fischer, F. (2019). Knowledge politics and post-truth in climate denial: On the social construction of alternative facts. Critical Policy Studies, 13(2), 133-152. https://doi.org/10.1080/19460171.2019.1602067

Foucault, M. (2008). The birth of biopolitics: Lectures at the Collége de France, 1978-1979 (Ed., M. Senellart). New York: Palgrave Macmillan.

Freire, P. (2013). Extensão ou Comunicação. Paz e Terra.

Freire, P. (2018). Pedagogy of the oppressed. Bloomsbury publishing USA

Gross, P. R., \& Levitt, N. (1994). Higher Superstition: The Academic Left and Its Quarrels with Science. Johns Hopkins Press.

Gutiérrez, R. (2013). The sociopolitical turn in mathematics education. Journal for Research in Mathematics Education, 44(1), 37-68. https://doi.org/10.5951/jresematheduc.44.1.0037

Hodson, D. (1994). Seeking directions for change: The personalisation and politicisation of science education. Curriculum Studies, 2(1), 71-98. https://doi.org/10.1080/0965975940020104

Hodson, D. (2003). Time for action: Science education for an alternative future. International Journal of Science Education, 25(6), 645-670.

Hurlbut, J. B. (2017). A science that knows no country: Pandemic preparedness, global risk, sovereign science. Big data and society, 1-14. https://doi.org/10.1177/2053951717742417

Jasanoff, S. (2004). The idiom of co-production. In S. Jasanoff (Ed.), States of Knowledge: The Co-production of Science and Social Order (pp. 1-45). Routledge.

Jasanoff, S. (2015). Future imperfect: Science, technology, and the imaginations of modernity. In S. Jasanoff \& S.-H. Kim (Eds.), Dreamscapes of modernity: Sociotechnical imaginaries and the fabrication of power (pp. 1-33). University of Chicago Press.

Jasanoff, S., \& Simmet, H. R. (2017). No funeral bells: Public reason in a 'post-truth' age. Social Studies of Science, 47(5), 751-770.

Jasanoff, S., et al. (2020). Comparative Covid Response: Crisis, Knowledge, Politics. Harvard University Press.

Jeong, S., Sherman, B., \& Tippins, D. J. (2021). The Anthropocene as we know it: Posthumanism, science education and scientific literacy as a path to sustainability. Cultural Studies of Science Education. https://doi.org/10.1007/s11422-021-10029-9

Kampourakis, K. (2019). Science, Society, and Scientific Literacy. Science \& Education, 28(6), $603-604$.

Kleinman, D. L. (2003). Impure cultures: University Biology and the World of Commerce. Madison: The University of Wisconsin Press

Knorr-Cetina, K. (1981). The manufacture of knowledge: An essay on the constructivist and contextual nature of science. In Science Observed: Perspectives on the study of science. Sage.

Krenak, Ailton (2020a). A Vida não é útil. São Paulo: Companhia das Letras.

Krenak, Ailton (2020b). Ideias para adiar o fim do mundo. São Paulo: Companhia das Letras. 
Kuhn, T. (1996). The structure of Scientific Revolutions. The University of Chicago Press.

Lakoff, A. (2017). Unprepared: Global Health in a Time of Emergency. University of California Press.

Latour, B. (1988). Science in Action: How to follow scientists and engineers through society. Harvard University Press.

Latour, B. (1993). We have never been modern. Harvard University Press.

Latour, B. (1997). Socrate's and Callicles' Settlement, or the Invention of the Impossible Body Politic. Configurations, 2, 189-240.

Latour, B. (1999). Pandora's Hope: Essays on the reality of Science Studies. Harvard University Press.

Latour, B. (2004a). Why Has Critique Run out of Steam? From Matters of Fact to Matters of Concern. Critical Inquiry, 30(2), 225-248. https://doi.org/10.1086/421123

Latour, B. (2004b). Whose cosmos? Which cosmopolitics? A commentary on Ulrich Beck's peace proposal. Common Knowledge, 10(3), 450-462.

Latour, B. (2005). Reassembling the Social: An Introduction to Actor Network Theory. Oxford University Press.

Latour, B. (2017a). Où atterrir?Comment s'orienter en politique. La Découverte.

Latour, B. (2017b). Facing Gaia: Eight Lectures on the New Climatic Regime. Polity.

Latour, B., \& Woolgar, S. (1986). Laboratory Life: The construction of scientific facts. Princeton University Press.

Lemke, J. L. (2001). Articulating communities: Sociocultural perspectives on science education. Journal of Research in Science Teaching, 38(3), 296-316. https://doi.org/10.1002/1098-2736(200103)38:3\% 3c296::AID-TEA1007\%3e3.0.CO;2-R

Lima, N. W., Vazata, P. A. V., Guerra, A., de Cavalcanti, C. J., \& H., \& Ostermann, F. (2019). Science Education in Post-Truth Age: Metaphysical Reflections from Bruno Latour's Science Studies. Revista Brasileira De Ensino Ciências, 19, 155-189.

Mackenzie J., Good R., \& Brown J.R. (2014). Postmodernism and science education: an appraisal. In, M. Matthews (Eds), International Handbook of Research in History, Philosophy and Science Teaching. Dordrecht: Springer.ur, B. (2017). Où atterrir? Comment s'orienter en politique. Paris: La Découverte.

Mbembe, A. (2019). Necropolitics. Duke University Press.

Mcintyre, L. (2018). Post-Truth. MIT Press.

Merton, R. K. (1938). Science, technology and society in seventeenth century England. Osiris, 4, 360-632.

Moura, C. B., Nascimento, M. M., \& Lima, N. W. (2021). Epistemic and Political Confrontations Around the Public Policies to Fight COVID-19 Pandemic. Science \& Education. https://doi.org/10.1007/ s11191-021-00193-3

Oreskes, N., \& Conway, M. (2010). Merchants of Doubt: How a Handful of Scientists Obscured the Truth on Issues from Tobacco Smoke to Global Warming. Bloomsbury Press.

Oxford Dictionary. (2016). Oxford Dictionary 2016 word of the year. Recuperado em 22 de setembro, 2018, de https://en.oxforddictionaries.com/word-of-the-year/word-of-the-year-2016

Petty, R. E., \& Cacioppo, J. T. (1986). The elaboration likelihood model of persuasion. In Communication and persuasion (pp. 1-24). Springer.

Popper, K. (1963). Conjectures and Refutations: The Growth of Scientific Knowledge. Routledge.

Rousseau, J.J (1750). Discourse on the Arts and Sciences. Available at https://www.stmarys-ca.edu/sites/ default/files/attachments/files/arts.pdf

Santos, B. S. (2008). Um Discurso Sobre as Ciências. São Paulo: Cortez.

Santos, B. de S. (2019). O Fim do Império Cognitivo - A Afirmação das Epistemologias do Sul. Belo Horizonte: autêntica.

Santos, B. de S. (2020). A Cruel Pedagogia do Vírus. Coimbra: Almedina.

Santos, B. de S., \& Meneses, M. P. (2009). Epistemologias do Sul. Coimbra: Edições Almedina SA.

Shinn, T., \& Ragouet, P. (2005). Controverses sur la science. Pour une sociologie transversaliste de l'activité scientifique. Lectures, Les livres.

Sjöström J., Eilks I. (2018) Reconsidering Different Visions of Scientific Literacy and Science Education Based on the Concept of Bildung. In: Dori Y.J., Mevarech Z.R., Baker D.R. (eds) Cognition, Metacognition, and Culture in STEM Education. Innovations in Science Education and Technology, vol 24. Springer, Cham. https://doi.org/10.1007/978-3-319-66659-4_4.

Sokal, A., \& Bricmont, J. (1998). Fashionable Nonsense: Postmodern Intellectuals' Abuse of Science. Picador.

Stengers, I. (2003a). Cosmopolitics I. University of Minnesota Press.

Stengers, I. (2003b). Cosmopolitics II. University of Minnesota Press.

Stengers, I. (2011). Thinking with Whitehead: A free and wild creation of concepts. Harvard University Press. 
Stengers, I. (2018). A proposição cosmopolítica. Revista do Instituto de Estudos Brasileiros, Brasil, 69, p. $442-464$

Stengers, I. (2020). Réactiver Le Sens Commun - Lecture de Whitehead en temps de débâcle. La Découverte.

Stetsenko, A. (2008). From relational ontology to transformative activist stance on development and learning: Expanding Vygotsky's (CHAT) project. Cultural Studies of Science Education, 3(2), 471-491. https://doi.org/10.1007/s11422-008-9111-3

Tolbert, S., \& Bazzul, J. (2017). Toward the sociopolitical in science education. Cultural Studies of Science Education, 12(2), 321-330. https://doi.org/10.1007/s11422-016-9737-5

Vrieze, J. (2017). Bruno Latour, a veteran of the 'science wars,' has a new mission. Science. Recuperado, em 22 de setembro, 2018, de http://www.sciencemag.org/news/2017/10/latour-qa

Whitehead, A. N. (1925). Science and the Modern World. Pelican Mentor Book.

Woolgar, S. (1982). Laboratory Studies: A comment on the state of the art. Social Studies of Science, 12, 481-498.

Publisher's Note Springer Nature remains neutral with regard to jurisdictional claims in published maps and institutional affiliations. 